\title{
THE EXPANSION OF JAMA'AH TABLIGH MOVEMENT AND ITS INFLUENCE ON THE RELIGIOUS BELIEF OF THE BAJO PEOPLE IN SOUTH EAST SULAWESI \\ Benny Baskara
}

Halu Oleo University, Kendari - Indonesia | benbasku@gmail.com

\begin{abstract}
Jama'ah Tabligh came to Southeast Sulawesi in the first decade of this century and soon spread among the Bajo people in the province. It's developed and contributed to the Bajo people in a significant way. This article describes the reason behind the expansion and the influence of Jama'ah Tabligh on them. Using historical approach, this study finds that the Bajo people accept Jama'ah Tabligh for some peculiar reasons. They are attracted to Jama'ah Tabligh because of effective and persuasive da'wah launched by this Islamic group. In addition, Jama'ah Tabligh seems to be the only Islamic da'wah that operate at the grassroots level in the region, which facilitates local curiosity to know more and finally join the movement. The non-political nature of Jama'ah Tabligh also helps bolster the immediate acceptance of Jama'ah Tabligh by the Bajo people. Jama'ah Tabligh has transformed the Bajo people in many ways, allowing them to become more orthodox due to its puritan nature. The Bajo people then no longer practice syncretic religious rituals. They do not speak their vernacular language anymore and they put on thawb and turban as their clothing. Nonetheless, Jama'ah Tabligh also brings about the teachings that are objects of criticism, namely kburuj and fatalism.
\end{abstract}

Keywords: Jama'ah Tabligh movement, religious belief, the Bajo people.

\section{Introduction}

The Bajo, sometimes spelled 'Bajau', refers to the community which is widely known as 'the people of the sea'. Their life, activities and identities are based on and closely related with the sea. ${ }^{1}$ They are

\footnotetext{
${ }^{1}$ Horst Liebner, "Four oral versions of a story about the origin of the Bajo people of southern Selayar," K. Robinson and M. Paeni (eds), Living Through Histories; Culture, History and Social Life in South Sulawesi, (Canberra: The Australian National University, 1998), pp. 19-23.
} 
considered as the most distantly dispersed and, at the same time, widespread indigenous ethnic group in Southeast Asia. Formerly, they were the sea nomads who live nomadic on their traditional boat called leppa. Because of this way of live, the Bajo people can be found across areas of Southeast Asian waters; most of them now live in Indonesia, Malaysia, and the Philippines. Despite the long history of the nomadic tradition, most of the Bajo are already settled by now. They build their houses on the sea near the shores or atolls formed floating settlements. The area is now widely known as kampung Bajo (Bajo village). This article, though, focuses on the Bajo people in South East Sulawesi.

There are many changes regarding their socio-cultural life. The change is likely due to their developing relationship with people from mainland. ${ }^{2}$ As result of the interaction, the culture of the Bajo is syncretic. ${ }^{3}$ The unique characteristic is noticeable in their language. Even though the Bajo people have their own language called baong sama, there are varied words and dialects used in practice due to the influence from local languages of their neighbor community. It is no surprise to see that the syncretic also appears in their religious belief. ${ }^{4}$ Even though most of the Bajo people consider Islam as their religion, it is more as cultural identity, with less commitment to practicing its doctrines and rituals. Therefore, they cannot be categorized as the 'devoted' Muslims. In their practice, they, they combine Islamic belief with their indigenous belief that mostly expressed in their traditional rituals, which reflects the syncretic form of their religious belief.

In relation to that, it is worth highlighting that the Bajo are not immune from external influence. Their life, along with the ways in which their culture and practices developed and change, is also closely related to the development of their surroundings. This is evidenced by

\footnotetext{
2 Saidatul Nornis Hj. Mahali, "Latar Masyarakat Bajau," Saidatul Nornis Hj. Mahali (ed.), Bajau Pantai Barat (Sabah: Universiti Malaysia Sabah, 2012); Md. Saffie Abd. Rahim and Ramzah Dambul, "Identiti Etnik Bajau Pantai Timur," Md. Saffie Abd. Rahim, Sabihah Osman, and Ramzah Dambul (eds), Bajau Pantai Timur (Sabah: Universiti Malaysia Sabah, 2012); Gusni Saat, Sama Bajau dalam Kanca Urbanisasi: Pengalaman di Teluk Bone, Sulawesi Selatan (Kuching: Universiti Malaysia Sarawak, 2010).

${ }^{3}$ Kazufumi Nagatsu, "Maritime Diaspora and Creolization: Genealogy of the SamaBajau in Insular Southeast Asia," Senri Ethnological Studies, 95 (2017), pp. 33-62; Idem, "Social Space of the Sea Peoples: A Study on the Arts of Syncretism and Symbiosis in the Southeast Asian Maritime World," The Journal of Sophia Asian Studies, 33 (2015), pp. 111-140.

${ }_{4}^{4}$ Benny Baskara, Islam Bajo: Agama Orang Laut (Jakarta: Javanica, 2016).
} 
the syncretic culture of the Bajo people. The influence is unavoidable as there is a quite intensive interaction of the Bajo community with people from the land; they need this to survive. At the end, the close relationship has resulted in the ways in which the Bajo community develop their own changes in culture and practices. ${ }^{5}$

Interestingly, one of the influences comes from Jama'ah Tabligh movement. As one of the transnational Islamic movements, Jama'ah Tabligh has spread rapidly in Southeast Asia. This is indicated by the increasing Islamic activism and engagement in Southeast Asia within the last decade. ${ }^{6}$ In Indonesia, the spread is even more apparent especially after the fall of New Order regime. ${ }^{7}$ The expansion of Islamic transnational movements itself is perceived as a threat to the way of Islam being embraced by Indonesian Muslims. ${ }^{8}$ The threat is especially identified with their campaign to impose a more orthodox Islamic teachings and to abolish traditional practices. It surely is interesting to see the interaction between such idea with communities like the Bajo community.

This paper wants to explore the ways in which the Jama'ah Tabligh movement interacted with the Bajo along with the influence and impact upon their religious belief. In so doing, this paper will answer three primary questions: (1) How does the expansion of Jama'ah Tabligh movement reach rural areas and indigenous peoples particularly the Bajo community of South East Sulawesi; (2) How the Bajo people are influenced, accepted, and finally embraced Jama'ah Tabligh teachings; and (3) How the influence of Jama'ah Tabligh teachings gives impact to the life of the Bajo people, especially to their religious belief.

\footnotetext{
5 A.B. Lapian, Orang Laut, Bajak. Laut, Raja Laut: Sejarab Kawasan Laut Sulawesi Abad XIX (Depok: Komunitas Bambu, 2009); F.R. Zacot, Orang Bajo, Suku Pengembara Laut (Jakarta: Gramedia, 2008).

${ }^{6}$ J.L. Liow, "Islamism in Southeast Asia," Kyoto Review of Southeast Asia 23 (2018).

7 Sumanto Al-Qurtuby, "Indonesia's Islamist Mobilization," Kyoto Review of Southeast Asia 23 (2018).

8 Abdurrahman Wahid, Ilusi Negara Islam: Ekspansi Gerakan Islam Transnasional di Indonesia (Jakarta: LibForAll Foundation, 2009).
} 


\section{Jama'ah Tabligh Movement in Indonesia}

The Jama'ah Tabligh movement was established around 1927 in Mewat, North India, by Maulana Ilyas Al-Kandahlawi. ${ }^{9}$ The leadership is then continued by his successors, Maulana Yusuf Al-Kandahlawi, and Maulana Zakariya Al-Kandahlawi. ${ }^{10}$ It is Maulana Zakariya AlKandahlawi who then compiled the main teachings of the Jama'ah Tabligh into a copious book under the title Fada'il al-A'mál (the virtue of good deeds), which become the main reference for all its adherents. The mission of Jama'ah Tabligh movement mainly is to realize their version of ideal Muslim society and bring back Muslims to 'true Islam'. True Islam in their believe is the one in line with the teachings of Prophet Muhammad. ${ }^{11}$

Since its first establishment almost a century ago, this movement has since spread from India to all over the world. Jama'ah Tabligh is believed to arrive and enter Southeast Asia in 1952 with the first delegation of the Jama'ah led by Maulana Haji Miaji Isa landed in Penang (Malaysia), Medan (Indonesia), and Singapore. ${ }^{12}$ Another version offer theory that Jama'ah Tabligh was firstly introduced in Southeast Asia by Maulana Abdul Malik Madani, who came to Singapore, Selangor and Kuala Lumpur (Malaysia), which also happened in 1952. ${ }^{13}$ From those two versions, although they differ on who and where the Jama'ah Tabligh was firstly introduced, both agree that the spread and development of the Jama'ah Tabligh was helped and supported by Indian Muslim communities be it in Singapore, Malaysia, or Indonesia. ${ }^{14}$

In Indonesia, since the first arrival of delegation of the Jama'ah Tabligh in Medan, North Sumatra, in 1952, they expanded their

\footnotetext{
${ }^{9}$ Farish A. Noor, Islam on the Move: The Tablighi Jama'at in Southeast Asia (Amsterdam: Amsterdam University Press, 2012); Idem, "Pathans to the East! The Development of the Tablighi Jama'at Movement in Northern Malaysia and Southern Thailand," Comparative Studies of South Asia, Africa and the Middle East 27, 1 (2007), 7-25; Kamaruzzaman Bustamam-Ahmad, "The History of Jama'ah Tabligh in Southeast Asia: the Role of Islamic Sufism in Islamic Revival," Al-Jami'ah 46, 2 (2008), 353-400.

${ }^{10}$ Noor, Islam on the Move.

11 Ibid.; Noor, "Pathans to the East!"; Bustamam-Ahmad, "The History of Jama'ah Tabligh".

12 Noor, Islam on the Move.

13 Bustamam-Ahmad, "The History of Jama'ah Tabligh".

${ }^{14}$ Noor, Islam on the Move; Bustamam-Ahmad, "The History of Jama'ah Tabligh".
} 
movement to the middle part, and later to the eastern part of Indonesia. The second delegation of Jama'ah Tabligh landed in Jakarta in 1955. Their first destination is Indian Muslim community in Jakarta, and they were accommodated by Haji Zaristan, an Indonesian citizen of Indian origin, at his house. After three days at Haji Zaristan's house, the Jama'ah Tabligh delegations moved to Bandengan mosque in North Jakarta, which became the first markas (basis) for their da'wah movement. However, after two years, their da'wah program has not achieved great success with influence that only affects the community surrounding the mosque. They then move again to search for a better location. At that time, they then moved to Kampung Jeruk mosque in Jakarta in $1957 . .^{15}$ Since they felt that this mosque was appropriate to be their markas, they still make it a home base for them until recent times.

From Jakarta, which was located in the west part of Java, the Jama'ah Tabligh then expanded their movement to central and eastern part of Java. After the first arrival of Jama'ah Tabligh delegation in Jakarta in 1955, they were already even able to send another delegation to Surakarta (Solo) within the same year. In Surakarta, the delegation was welcomed warmly by Kyai Muhammad Tofail, a leading figure of Indian merchant community in Surakarta. The Indian Muslim community in Surakarta were considered as wealthy and influential at that time; they were able to build some mosques in Solo. One of the mosques they built is An-Ni'mah mosque in Tanjung Anom, Surakarta, which soon became the markas of their movement. Kyai Muhammad Tofail was then also appointed as the first emir (leader) of Jama'ah Tabligh in Surakarta. ${ }^{16}$

Besides becoming the markas for the da'wah activity in Surakarta, An-Ni'mah mosque also became the base for sending Jama'ah Tabligh delegations to other cities in central and east Java. After spending years sending many delegations to various cities in central and east Java, Jama'ah Tabligh seemed to gain only a small success in their da'wah campaign. However, after almost thirty years of effort and hard work in their da'wah, they finally made the breakthrough in 1984 when they

\footnotetext{
${ }^{15}$ Noor, Islam on the Move; Farish A. Noor, "The Spread of the Tablighi Jama'at across Western, Central, and Eastern Java and the Role of the Indian Muslim Diaspora," RSIS Working Papers Series, No. 175 (Singapore: Nanyang Technological University, 2009).

16 Noor, Islam on the Move; Noor, The Spread of the Tablighi Jama' at.
} 
won great support from local Kyai (Muslim leader), along with his santri (pupils) and local villagers, of Temboro village, Magetan, East Java. It was Kyai Uzairon, the son of Kyai Mahmud Siddik, the founder of AlFattah pesantren (traditional Islamic boarding school), who embraced Jama'ah Tabligh teaching, along with his santris (students). Soon, he then was appointed as emir of Jama'ah Tabligh, and Al-Fattah pesantren continuously expanded. Nowadays, with thousands of santri and hundreds of ustadh (religious teacher), Al-Fattah becomes the largest Jama'ah Tabligh pesantren in Indonesia. In addition, together with the support from local villagers, it also makes Temboro as the biggest Jama'ah Tabligh center in Indonesia. Therefore, the major gathering of Jama'ah Tabligh (Jor Ijtima/Jor Qodama) are often held in Temboro, which is attended by the adherents from Indonesia and overseas.. ${ }^{17}$

After gaining success in Java, the Jamaah Tabligh then expanded their movement to the eastern part of Indonesia such as Bali, Nusa Tenggara, Sulawesi, and Maluku. The Jama'ah Tabligh movement even has already reached Papua, the furthest and the easternmost province of Indonesia. ${ }^{18}$ The center of Jama'ah Tabligh activity in eastern part of Indonesia is located in Makassar, Southeast Sulawesi. In the beginning, around 1980's, the Jama'ah Tabligh in Makassar took Mamajang Raya mosque, Makassar, as their base, ${ }^{19}$ and later at the Grand Mosque of Kerung-Kerung. This mosque then served as the permanent base for their da'wah movement. ${ }^{20}$ The strategic position of Makassar as the center for Jama'ah Tabligh movement in all Sulawesi and eastern part of Indonesia in general, including the Bajo adherents from Kendari, Southeast Sulawesi.

\section{Jama'ah Tabligh's Teachings}

The main core of all Jama'ah Tabligh teachings is contained in the Fad̄a'll al-A'mál book, written by their ulama, Zakariya Al-Kandahlawi. This book contains several parts or chapters, they are: (1) biographies

\footnotetext{
${ }^{17}$ Noor, Islam on the Move; Noor, The Spread of the Tablighi Jama'at.

18 Farish A. Noor, "The Arrival and Spread of the Tablighi Jama'at in West Papua (Irian Jaya), Indonesia," RSIS Working Papers Series, No. 191 (Singapore: Nanyang Technological University, 2010).

19 Adlin Sila, "Kasus Jama'ah Tabligh di Makassar Sulawesi Selatan dan Magetan Jawa Timur," Ahmad Syafi'í Mufid (ed.), Perkembangan Paham Keagamaan Transnasional di Indonesia (Jakarta: Kementerian Agama, 2011); Noor, Islam on the Move.

20 Sila, "Kasus Jama'ah Tabligh"; Noor, Islam on the Move.
} 
of the Șậabah (companions of Prophet Muhammad); (2) Fada'tl alQur'an (the excellence of the Quran); (3) Fad da' of prayers); (4) Fada'tl of Driker (the excellence of remembrance to

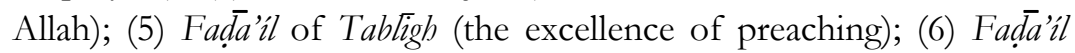
Ramadan (the excellence of Ramadan); and (7) Muslim Degeneration and its remedy. From those seven chapters, the significant chapters that have the most directive influence and impact on their movement are chapter five and chapter seven. Chapter five is about the virtue to preach while chapter seven explains about Muslim degeneration and offer what they believe as the only solution. In other words, the motivation for their da'wah actually is to preach the excellence of Islam, and to "heal" the Muslim communities whom they see as degenerated by bringing them back to what they consider as the true Islamic teachings. In relation to the book, other chapters are actually playing roles as supporting the mentioned two chapters, chapter five and seven. For example, chapter three and four explain about salah and dhikr. It is safe to say that those activities that they perform in the mosque become the reason or media for them to approach other Muslims and preach them to follow their path and join their movement. In addition, the first chapter which is about the stories of the sabajab actually is more as motivation for them to emulate the lifestyle of Prophet Muhammad with his companions.

Meanwhile, Jamaah Tabligh in practice holds six fundamental principles (al-usül al-sittah or saat batein), they are: (1) Kalimat Tawhid or Shabadah (the Muslim profession of faith); (2) upholding the prayers, especially five times prayers a day, with full concentration and full submission (khushu' and khudū'); (3) 'ilm (knowledge, especially knowledge of Allah's command) and dzikr, (4) ikram al-Muslimin or respecting the Muslims; (5) ikblas or sincerity, pure intentions, and selfappraisal; and (6) tafrigh al-waqt or to spare time. In this case, tafrigh alwaqt means that every Jama'ah Tabligh follower/adherent/individual? is expected to allocate time for da'wah and khuruj, literally mean going out from home and do the preaching to invite other Muslims obeying the commands of Allah and Prophet Muhammad's. ${ }^{21}$ Furthermore,

${ }^{21}$ Sila, "Kasus Jama'ah Tabligh"; M. Talib, "The Tablighis in the Making of Muslim Identity," Mushirul Hasan (ed.), Islam, Communities and the Nation, Muslim Identities in South Asia and Beyond (New Delhi: Manohar Publishers, 1998). 
Talib adds one more fundamental principle and it is tark-i layani or abdicating the unnecessary. Based on this principle, the Jama'ah Tabligh encourage their adherents to take a path of simple life as the only thing that matters is the obedience to Allah's commands. As a consequence, the others or the rest of what are in this life are pointless, or not worthy and hence should be renounced. ${ }^{22}$

The khuruj or obligation to go out from and leave the house for dakwa, is becoming one of the peculiar or unique characters of the Jama'ah Tabligh that distinguish themselves from other Muslims or adherents of other organizations. The word kburüj itself is an Arabic word, which literally means "going out". Meanwhile, the operational definition according to the Jama'ah Tabligh 's principle, kburuj means "the practice of going out into the world for days, weeks, or months in order to bring the message of the Jama'ah Tabligh (teachings) to other Muslims." ${ }^{23}$ In general, there are three types of khuruj: three days, forty days, and four months. According to their fundamental principle, the Jama'ah Tabligh requires their adherents to perform three days kburuj in one month (monthly), forty days khurü in a year (annually), and four month khuruj, at least, once in a life for every individual.24

On the other hand, the da'wah activity for women is called masturah. The word masturah is also an Arabic word, which literally means "covered behind the veil". ${ }^{25}$ In this context, the term masturah can be defined as the da'wah program that is designated for women only with no man is allowed to be involved within. The masturah is usually conducted in line with khuruj, but it is only for short term. They are 3, 14 , and maximum 40 days. In addition, if the base for man's khuruj is the mosque, the masturah on the other hand is conducted within the house surrounding the mosque. The house is usually the residence of a member of Jama'ah Tabligh whose husband is performing kburuj. ${ }^{26}$

\footnotetext{
22 Talib, "The Tablighis, 207-340

${ }^{23}$ Noor, Islam on the Move.

24 Abdul Aziz, "The Jama'ah Tabligh Movement in Indonesia: Peaceful Fundamentalist," Studia Islamika 11, 3 (2004), 467-518.

25 Sakdiah, "Masthurah dalam Dakwah Jama'ah Tabligh: Analisis Metode dan Praktek," Al-Idarah 1, 1 (2017), 67-86.

${ }^{26}$ Ibnu Radwan Siddik, "The Husband's Obligation in Giving Religious Education for His Wife According to Compilation of Islamic Law and its Implementation on
} 
Activities that are usually held within and during the matsurab include ta Tim wa al-ta 'allum (teaching and learning), mudhäkarab (discussion), dhikr (remembrance of Allah) and worship, as well as bayan (lecture). ${ }^{27}$ It is expected that, with her participation in the masturah, the women of Jamaah Tabligh women will have six pious characteristics and they are: muta'allimah (learned), murabbiyah (educator, especially for their children), 'abidah (devout Muslim), zabidah (ascetic, developing simple and modest life), khadimah (good servant, for her husband and family), and finally da $\bar{a}_{y}$ ab (woman preacher, who preach Islam to other Muslim women). ${ }^{28}$

\section{The Expansion of Jama'ah Tabligh Movement to the Bajo}

The Jama'ah Tabligh movement first came to Southeast Sulawesi around 2007-2008. Its base is at Babus Salam mosque in a village called Petoaha, Kendari. The Bajo community in Petoaha built Babus Salam mosque which was originally was built under the program of Tentara Masuk Desa (TMD - Army program for assisting and developing village) in 2005. The expansion of Jamaah Tabligh movement in Kendari, and Southeast Sulawesi in general, is highly influenced by their movement in Makassar, as the center or markas of Jama'ah Tabligh movement for Sulawesi and eastern part of Indonesia. In other words, it was the Jama'ah Tabligh adherents from Makassar who spread and expanded Jama'ah Tabligh movement in Kendari and Southeast Sulawesi in general. The Jama'ah Tabligh in Kendari started to operate their movement in the 1990's, and continued to expand their movement until the beginning of 2000's. ${ }^{29}$ At first, the activity of Jama'ah Tabligh movement took place at mosques in Kendari. ${ }^{30}$ This is before they finally could build Baitul Muslimin mosque in Wanggu, Kendari as their headquarter for their activities in Kendari and Southeast Sulawesi, and Kasyiful 'Ulum boarding school as the center

Tablighi Jama'at in Serdang Bedagai, North Sumatra, Indonesia," IOSR Journal of Humanities and Social Science 22, 4 (2017), 93-99.

27 Ibid.

28 Sakdiah, "Masthurah dalam Dakwah"; Siddik, "The Husband's Obligation".

29 Abdul Khawiyu, "Pemberian Nafkah Terhadap Keluarga, Studi Kasus Aktifitas Khuruj Jama'ah Tabligh di Kota Kendari,” Jurnal Syariah Hukum Islam 2, 1 (2019): 1-15.

${ }^{30}$ Ibid. 
for their education in Kambu, Kendari, in 2009. ${ }^{31}$ From their arrival to the beginning of 2000's, Jama'ah Tabligh gained quite significant number of adherents. Interestingly, the success is partly due to the absence of other Islamic transnational movements especially Salafi movements, that later proven to be tough competitors. In the mid of 2000 's, the other movements arrive and they show similar style of da'wah (preaching), very intensive and pro-active in the attempts to gain new adherents. 32

Aside from that, one interesting finding related to Jama'ah Tabligh and the Bajo is the ways in which interaction and relation being developed between them. At first, when Jama'ah Tabligh movement entered their village, the Bajo people joined the activities of Jama'ah Tabligh merely out of curiosity. Nevertheless, after quite sometimes, they then became devoted adherents of Jama'ah Tabligh. There are indeed several explanations on how Jama'ah Tabligh finally spread quite vastly among the Bajo people. One of the explanations is that the characteristics of the Bajo made the spread of Jama'ah Tabligh quite smooth. Their characteristic in general is quite similar to the attribute of other ethnic groups in Sulawesi, heavily influenced by a patronclient pattern of relationship. ${ }^{33}$ In this pattern of relationship, people with no considerable amount of power play roles as client. Here, they tend to depend on the other part of the society that has power, the socalled patron. Unsurprisingly, once the prominent figures who play roles as patron join the Jama'ah Tabligh, their clients and the rest of society would follow their path.

Interestingly, there are indeed a few number of the Bajo people who are resistant and refuse to follow and join the Jama'ah Tabligh movement. These resistant Bajo people are those who have more experience and broader relationship network than the ordinary Bajo. They already have had a more intense relation and interaction with people from the mainland. They also are the ones who have better opportunities to learn and study deeper and more comprehensively about Islam. Hence, they are also more aware with the variety of

31 Angki Firmansyah, "Manajemen Kurikulum Pondok Pesantren Salafiyah Dalam Penyelenggaraan Program Dakwah Jamaah Tabligh,” Zawiyah 4, 1 (2018): 102-115.

32 Saprillah, "Gerakan Salafisme di Kota Kendari," Mimikri 3, 1 (2017): 1-14.

33 C. Pelras, The Bugis (Oxford: Blackwell Publishers, 1996); H.S. Ahimsa-Putra, Minawang: Hubungan Patron-Klien di Sulawesi Selatan (Yogyakarta: Gadjah Mada University Press, 1988). 
Muslim movements along with their arguments. In other words, they know some problems with Jama'ah Tabligh teachings and decided not to join it. They are aware that some of the teachings of Jama'ah Tabligh are not compatible with social and cultural context of the Bajo society. In addition to that, they can point out reasonable arguments defending their stance that is refusing to join Jama'ah Tabligh movement. Nevertheless, as mentioned briefly, they are minority as the majority of the Bajo people have become the adherents of the movement.

It is important to note that Jama'ah Tabligh maintain a continuous and consistent routines in maintaining their jama'ah. They usually have a regular gathering in the mosque called as musyawarab. The musyawarah in Babus Salam mosque is usually held after Friday prayer. In the musyawarah, the theme of discussions mainly are the workplan for the da'wa. The details being discussed including details such as when, where, and who will responsible to do the da'wa. One interesting finding is that people who attend the Friday prayer mostly wear jubba or thawb (ankle length garment similar to robe, kaftan or tunic) that is identical with Arab or middle eastern style. Still, there are also some others who wear traditional clothing which is more identical with Indonesian styles that is sarong and peci (prayer cap). Among people who wear jubba, there are also some who wear turban to cover their head.

The Friday khutbah (sermon) is dominated by speeches giving emphasize to doctrines belittling the lure of profane life. To give illustration, the preacher will state that the real life is the life in the hereafter and the life in this world is merely an amusement and worthless. They often refer to and cite the verse about the certainty of death such as the verse of the Quran Chapter 21: 35), which means "Every soul will experience death". They will further stress the fact that the living being, including human being, will always encounter and suffer two incurable diseases; old age and death. In addition, they will also warn people and proclaim that the good people will be treated in a hospitable manner with the Angel of Death, Irrail, while the bad people will be treated in a contrast manner.

In this weekly routine musyawarah the person leading the musyawarah is called Umar, while the imam (leader) of the Friday prayer is called Abu Bakar. The Jama'ah Tabligh adherents usually take the name of the sahabat Nabi (companions of Prophet Muhammad), especially the 
four caliphs, to be their names or attributes. The musyawarah is usually attended by approximately 30 people. In the musyawarah, they discussed their working plan, to determine of when and where the da'wah should be carried out. In the musyawarah, it was offered to anyone from the jama'ah to be treasurer voluntarily, to take care the financial matters of the jama'ah. The plan to hold the monthly jor (jawr) is also discussed in the musyawarah, which will be held in this mosque in the second week every month, and the estimated time is ba'da ashar (after afternoon prayer). Jor (jawr) is the peculiar term used by Jama'ah Tabligh to denote a big musyawarah or a big gathering among them, which is held regularly, usually monthly until annually, and regarding its scale, it is attended by the adherents from faraway, such as from outside the city or even from abroad.

Another routine is the activity of Fadbilah Amal book recitation which is usually conducted after maghrib (evening) prayer until approaching isya' (night) prayer. In this occasion, the Fadhilah Amal is recited and led by an ustäh with the jama'ah are listening to him. Interestingly, the jama'ab are only listening to the recitation with nobody makes any note for the recitation. Besides Fadhilah Amal, another book that also usually recited is Subh al-ssalam, with the same method.

It is worth noting that the da'wah activity of Jama'ah Tabligh in Petoaha has already spread all over places outside the village, In Petoaha itself, the adherents of Jama'ah Tabligh have already become the majority of its populations (around 90 percent of them are estimated to be the adherents of Jama'ah Tabligh. Therefore, the da'wah activity should be directed to Muslims outside Petoaha. For the activity of dakwah involving travel to other places, the Jama'ah Tabligh develop the concept of khuruj (which literally means going out). It is important to note that, according to Tabligh teaching, someone who already performed khuruj for 40 days is deserved to be called ustädh (religious teacher), and if he already performed khurij for 4 months, then he is deserved to be called 'ulama (religious leader).

There is a testimony from one of the Jama'ah adherents regarding the strong position of jamaah tabligh in Makasar in general. The person actually also can be said as quite important particularly from the view of the Jamaah. He was ordained by Maulana Ilyas in India, and as a proof of his ordination, he was given a ring. He then told his story on his experience of kburüj to various places and, in particular, his 
participation in the great meeting of Jama'ah Tabligh in Makassar, South Sulawesi. He said that many leading figures already joined the movement and among them are Regent of Bombana and the Head of Bone Regency Police Department. He said that the Head of Bone Regency Police Department even requires all of his staff, all police officers in Bone Regency Police Department, to join khurüj at least for three days. He claimed that joining Jama'ah Tabligh and become its full adherent may improve someone's character, from bad or evil to be good and pious. He gave an example, an ex-felon from Makassar who was jailed for homicide cases transformed to be pious person after receiving and joining the teaching of Jama'ah Tabligh .

Among the explanations behind such success is the disciplined and reasonably organized plans of da'wah campaigns. In the monthly jor, there is always discussion regarding the dakwah plan along with its details including targets, persons, and timeline. To give illustrations, in one of the meeting, it is decided that the location of the dawah program is the Bajo villages. Those villages are around three regencies, Kendari, South Konawe, and North Konawe, and they are: TinanggeaTorobulu-Saponda-Mekar-Tondonggeu-Abeli. The jama'ab who attend the jor in Babus Salam mosque mostly are the Bajo people as the representatives of Jama'ah Tabligh from those areas, which also attended by other members of Jama'ah Tabligh who are not the Bajo people from other areas.

In the belief of Jama'ah Tabligh adherents, every step of the walk in performing da'wah, which is the door-to-door da'wah, is better and more valuable than to preach or to give sermon from one podium to another. The main reason behind this belief is that in the process of door-to-door dawah, they directly persuade Muslims to perform their obligation by real action, compared to preaching or sermons that only able to persuade Muslims by words. Furthermore, they believe that performing the door-to-door da'wah is similar to perform jibad, or to struggle in God's Way, for which they sacrifice their energy, time, career, money, and wealth. They also believe that being successful in attracting person to join Jama'ah Tabligh is much better and much more valuable than performing five daily obligatory prayers for 60 to 70 years.

However, because of this conviction, many Jama'ah Tabligh members undermine of worldly goods and have low motivation for temporal necessities of life. Moreover, they are also always being force- 
fed by the doctrine that the life in this world is just amusement, which makes their motivation of life even weaker. One of Jama'ah Tabligh adherents from Petoaha named Aslim is just came back from four months kburij to India-Pakistan-Bangladesh (IPB). The adherents of Jama'ah Tabligh even consider that the "IPB" is the "second holy land" after the Haramayn (the two harams: Mecca and Medina) in Arabia. Because he left for four-month kburüj, therefore his family, his wife and children, are abandoned and neglected. Questions frequently asked concerning this fact, how is his responsibility as the breadwinner of the family, when he put more priority to perform khuruj rather than to take care of his family.

In addition to the da'wah approach, there is also an interesting explanation behind the acceptance of the Bajo people towards the movement. Jama'ah Tabligh positioned themselves as a (seemingly and convincingly) a non-political movement. The characteristic of Jama'ah Tabligh that shows no political interest in their movement seems to play such a considerable role in its fast spread. The Bajo people, as a minority group with insignificant political representation and low involvement in politics in general, tend to feel suspicious and reluctant to anything imbued with political interests. The fact that Jama'ah Tabligh does put emphasize on the after-life causes and tend to belittle the recent life also has added values in attracting the people. In addition to be the minority, the Bajo are an impoverished community with little economic capital. Unsurprisingly, the teaching of the Jama'ah Tabligh that emphasize on simple way of life, humility, and reluctance to material wealth and worldly things do appeal and fit to the worldview and the life of the Bajo.

Moreover, the style of da'wah and communication of Jama'ah Tabligh also is quite 'soft' and non-judgmental. This is especially more apparent in comparison to other Islamic transnational movements, such as Salafi movement. Not only 'softer' in terms of not attacking the existing lifestyle and religious practices of the local people in places they visit, they also are more intensive and take the 'person to person' way of communication. Their dakwah and persuasion is conducted in a model that can be called as a door-to-door da'wa. This model involves the person from Jama'ah Tabligh goes knocking people's door, meet and greet them, and directly persuade them to join praying together with Jama'ah Tabligh in neighboring mosques. After prayers, usually they are also being persuaded to join other activities of Jama'ah 
Tabligh in the mosque. This method actually is the vanguard for Jama'ah Tabligh to search and to recruit potential adherents. The doorto-door da'wah is always conducted every Friday and Saturday, usually in the evening, approaching or after the time of maghrib (evening) prayer.

From the da'wah plan that discussed during the monthly jor described above, it can be inferred that Petoaha becomes the basis for the Tabligh movement for its expansion to other Bajo villages comprises three regencies in Southeast Sulawesi Province. The Bajo Tabligh adherents from Petoaha also become important actors for the preaching of Tabligh movements to their danakang (other Bajo) in other Bajo villages in Southeast Sulawesi. The location of Petoaha actually is not so far from the provincial basis of Tabligh movement for Southeast Sulawesi (markas da'wah Tabligh Sulawesi Tenggara) in Baitul Muslimin mosque, Wanggu, Kendari, where the distance to Petoaha is about $13 \mathrm{~km}$. With this relatively close distance, then it also enables the close relationship between Petoaha and the central base of Tabligh movement in Wanggu. When a greater event is held in Petoaha, it is usually attended by representatives from central base in Wanggu, and vice versa, when provincial or higher level of events are held in Wanggu, representatives from Petoaha usually attend the events. Even in Friday prayer held in Babus Salam mosque Petoaha, sometimes it led by imam (religious leader) from Wanggu, and continued with attending weekly musyawarah in the mosque. This fact actually implies that the position of Petoaha is quite important in the greater map of Jama'ah Tabligh movement in Southeast Sulawesi.

In terms of the incoming of influences from the land to the Bajo village, borders and distances between a Bajo village and the center of activities of the mainland people, such as a city, are also significant. In the case of Petoaha Bajo village, its location is very close, even it becomes part of Kendari, the capital city of Southeast Sulawesi Province. Therefore, the influence of urban life from Kendari, including Jama'ah Tabligh movement, seems quite easy to enter Petoaha and to be accepted by its inhabitants. As a comparison, there is another Bajo village named Mekar, which located around $30 \mathrm{~km}$ up north Kendari and belongs to another regency, Konawe Regency, where the influence from the city is less significant and the number of Jama'ah Tabligh adherents in this village are also much lesser than in Petoaha. From this comparative fact, it implies that the closer the 
distance between a Bajo village and the center of land people's activities or a city, the stronger the influence that may entered and accepted by the Bajo in this village, and vice versa, the further the distance, the lesser the influence from the land to the Bajo in the village.

\section{The Influence of Jama'ah Tabligh Movement on the Bajo's Religiosity}

After the elaboration on how the Jamaah Tabligh's success in their da'wab and the factors behind the acceptance of the Bajo people towards them, the following are explanation on how their existence within the Bajo has impacted their religiosity and lifestyle in general.

One of the quite apparent influences shows in how the Bajo society in Petoaha seems to have a more fatalist way of thinking. This shows in several aspects of their life. One example is the fact that they now consider that formal education is no longer important for their children. As a result, many Bajo children in Petoaha quit their school. Another way is that even if they finish their school, the do not continue schooling to subsequent formal education. Not only in realm of formal education, their motivation and work ethics also plummeted quite significantly. To give illustration, when the Bajo fisherman from Petoaha goes for fishing, they will feel enough for the day once they get, say, 1-2 kilograms of fish. Despite the fact that they still can continue to work and gain more, they choose to call the day and go home. So, they leave their work and turn their attention to perform ibadab in accordance to the teachings of the Jama'ah Tabligh .

From the description above, it can be inferred that after the Bajo followed Jama'ah Tabligh teachings, their life has tended to be more fatalistic. Indeed, for Western commonsense and some Western scholars, Islam itself is considered as a fatalistic religion ${ }^{34}$ and Muslim societies are considered as fatalist. ${ }^{35}$ The Jama'ah Tabligh itself is even accused by other Muslim groups as the fatalist too, because of their understanding and praxis of Islam based on the Prophetic history, which emphasize on the life history of Prophet Muhammad, especially on his humility, poverty, and reluctance to wealth accumulation, or

\footnotetext{
34 Helmer. Ringgren, "Islamic Fatalism," Helmer Ringgren (ed.), Fatalistic Beliefs in Religion, Folklore, and Literature (Stockholm: Almqvist \& Wiksell, 1967).

35 R. Littlewood and S. Dein, "Islamic Fatalism: Life and Suffering Among Bangladeshi Psychiatric Patients and Their Families in London," Anthropology \& Medicine 20, 3 (2013), 264-277.
} 
worldly things. ${ }^{36}$ This fatalistic view of Jama'ah Tabligh can also be compared to the fatalistic view in other religious traditions, such as Fransiscan Order in Catholicism, which emphasizes the poverty of Christ and the apostles. ${ }^{37}$

Several research had been done to investigate Islamic fatalism and its relation to various aspects in Muslim's life, such as facing and coping serious illness, ${ }^{38}$ road safety, ${ }^{39}$ and disaster preparedness. ${ }^{40}$ Although their findings are vary depending on different focus of study, but they share similar characteristic of the society they study, which is the fatalist view, stated that everything including human life is predetermined by God, out of human's control, and should be resigned or submitted to fate or God. Nevertheless, this view is also developed by the Bajo after they received Jama'ah Tabligh doctrines, especially on their stress that the real life is in hereafter, and worldly life is only a game. This doctrine seems strongly influence the Bajo's worldview, which make them develop fatalistic worldview and put over submission to God's fate and giving up hard work and diligent effort.

Another feature of Jama'ah Tabligh affects women dearly as it understands total subordination of wife to husband. It is reflected in the case of the wife who should obey her husband and serve him at her best. In their teaching, a wife should obey her husband and serve him at her best. Since Jama'ah Tabligh understand sex as the main purpose of marriage, a wife should do her best to fulfill the sexual desire of the husband. In order to ease or to smooth up this purpose, therefore it is recommended to the wife for not to wear underpants. ${ }^{41}$

\footnotetext{
${ }^{36}$ Noor, Islam on the Move.

37 Malcolm D. Lambert, Franciscan Poverty (St. Bonaventure, NY: Franciscan Institute Publications, 1998).

38 S. Hamdy, "Islam, Fatalism, and Medical Intervention: Lessons from Egypt on the Cultivation of Forbearance (Sabr) and Reliance on God (Tawakkul)," Anthropological Quarterly 82, 1 (2009), 173-196.

39 O. Simsekoglu et.al., "Risk Perceptions, Fatalism and Driver Behaviors in Turkey and Iran," Safety Science 59 (2013), 187-192; A. Kayani, M.J. King, and J.J. Fleiter, "Fatalism and Road Safety in Developing Countries, with a Focus on Pakistan," Journal of the Australasian College of Road Safety 22, 2 (2011), 41-47.

${ }^{40}$ H. Baytiyeh and M. Naja, "The Effects of Fatalism and Denial on Earthquake Preparedness Levels," Disaster Prevention and Management 25, 2 (2016), 154-167.

41 However, something embarrassing ever happened regarding this case. A Bajo woman had caught for not wearing underpants when she went to the market, by which she became a laughing stock for the people in the market.
} 
It is strongly assumed that this attitude is as a result of Tabligh matsurah (da'wah for women), especially the expectation that women should be a khadimah (good server) for her husband and family at all cost.

Another important finding is their religious expression such as the wearing of thawb and turban. Furthermore, because of this domination of the influence (hence not interaction which assumes mutual takeand-give in terms of influence), the Bajo people now have abandoned their traditional rituals. As mentioned briefly in the beginning of the paper, the Bajo are actually known to be Muslims with a unique syncretic religious way of life before they joined Jama'ah Tabligh. Among their lifestyle is a mixture of Islamic faith with their indigenous beliefs. To give an example, the Bajo's indigenous belief puts emphasize on the ancestor worshipping as they believe that the sea and all of its contents is guarded by their great ancestors. They also believe that the sea, and this is definitely important as their main source of life is from the sea, is the great heritage from their ancestors to them. How the Bajo respect and worship their great ancestors is reflected in their traditional rituals, which is indicated by drifting offerings to the sea, along with reciting incantations to their great ancestors. ${ }^{42}$

Meanwhile, as commonly known, the purist Islamic teachings, including Jama'ah Tabligh, obviously consider these practices, especially drifting offerings to the sea and reciting incantations to the ancestors, are "shirk", or idolatry which is a grave sin in Islam. The shirk practice should be avoided and abandoned by every Muslim since it may corrupt the faith. Moreover, according to the Jama'ah Tabligh teachings, the Bajo traditional rituals are considered as having no base in the 'pure' Islamic teachings. Hence, those practices are, in addition to be dangerous to the faith, are meaningless. The conclusion then is the obligation to abandon them. This is also part of following one of the Tabligh basic principles, "abdicating the unnecessary".

When the Bajo abandon their traditional religious rituals, the syncretic religious expression also disappears. This means that the religious identity of the Bajo has already changed or shifted. They are more looked as Jama'ah Tabligh adherents, either based on their outward appearances by using jubba (long dress), high prayer cap, and having beard for men, or based on their religious expression by performing worship following Jama'ah Tabligh teachings. Furthermore, the transformation of religious identity of the Bajo leads

42 Baskara, Islam Bajo. 
to the change of their identity in general. At a glance, common people will recognize them as Jama'ah Tabligh followers, not as the Bajo, unless they show their peculiar characteristics of their identity, such as their own language, or mentioning their living place at Bajo village. In other words, if they do not speak in their language (baong sama), or if they do not mention their living place at Bajo village. They are no longer identified as the Bajo. From this fact we can infer that among other factors, the influence of Jama'ah Tabligh teachings gives significant impact to the change or the shift of the Bajo identity in general.

\section{Conclusion}

The relatively swift acceptance of Jama'ah Tabligh by the Bajo people in Southeast Sulawesi relates to several factors, namely persistent and effective dakwah of Jama'ah Tabligh, curiosity, and the non-political character of Jamaah Tabligh movement. The impact of the expansion of the Jama'ah Tabligh movement to the Bajo religious belief especially is the acceptance of the Bajo to Jama'ah Tabligh teachings, which appears in their religious expression that already predominated by Jama'ah Tabligh teachings. The syncretic religious expression is no longer practiced. these traditional rituals are considered as something that are not useful or pointless, because it is not based on Islamic teachings. With this fact, then the religious identity of the Bajo is already changed because of their acceptance, and further predominated by, Jama'ah Tabligh teachings. They do not speak in their language (baong sama) nor wear the same clothing.

Nonetheless, as elsewhere in the archipelago, Jama'ah Tabligh dakwah is not always welcome by certain segment of local Muslims. Among the widely criticized teaching of Jamaa'ah Tabligh is the khuruj which necessitates abandonement of family for long period of time. Another aspect is the fatalistic aspect that is another main feature of Jama'ah Tabligh due to their focus on the causes of happiness in hereafter. Women status is also severely compromised in Jama'ah Tabligh as women existence is acknowledged to support men. These three features seems to fit the Bajo people who are from the first place not well-educated and economically impoverished.[] 


\section{References}

Ahimsa-Putra, H.S. Minawang: Hubungan Patron-Klien di Sulawesi Selatan. Yogyakarta: Gadjah Mada University Press, 1988.

Al-Qurtuby, Sumanto. "Indonesia's Islamist Mobilization." Kyoto Review of Southeast Asia (2018).

Aziz, Abdul. "The Jama'ah Tabligh Movement in Indonesia: Peaceful Fundamentalist." Studia Islamika 11, 3 (2004).

Baskara, Benny. Islam Bajo: Agama Orang Laut. Jakarta: Javanica, 2016.

Baytiyeh, H. and Naja, M. "The Effects of Fatalism and Denial on Earthquake Preparedness Levels." Disaster Prevention and Management 25, 2 (2016).

Bustaman-Ahmad, Kamaruzzaman. "The History of Jama'ah Tabligh in Southeast Asia: the Role of Islamic Sufism in Islamic Revival." Al-Jami'ah 46, 2 (2008).

Firmansyah, A. "Manajemen Kurikulum Pondok Pesantren Salafiyah Dalam Penyelenggaraan Program Dakwah Jamaah Tabligh." Zawiyah 4, 1 (2018).

Hamdy, S. "Islam, Fatalism, and Medical Intervention: Lessons from Egypt on the Cultivation of Forbearance ( $S a b r$ ) and Reliance on God (Tawakkul)." Anthropological Quarterly 82, 1 (2009).

Hortsmann, A. "The Tablighi Jama'at, Transnational Islam, and the Transformation of the Self between Southern Thailand and South Asia." Comparative Studies of South Asia, Africa and the Middle East 27, 1 (2007).

Kayani, A., MJ. King, and JJ. Fleiter. "Fatalism and Road Safety in Developing Countries, With a Focus on Pakistan." Journal of the Australasian College of Road Safety 22, 2 (2011).

Khawiyu, Abdul. "Pemberian Nafkah Terhadap Keluarga, Studi Kasus Aktifitas Khuruj Jama'ah Tabligh di Kota Kendari." Jurnal Syariah Hukum Islam 2, 1 (2019).

Lapian. A.B. Orang Laut, Bajak Laut, Raja Laut: Sejarah Kawasan Laut Sulawesi Abad XIX. Depok: Komunitas Bambu, 2009.

Liow, J.L. "Islamism in Southeast Asia." Kyoto Review of Southeast Asia 23 (2018). 
Littlewood, R. and S. Dein. "Islamic fatalism: Life and Suffering among Bangladeshi Psychiatric Patients and Their Families in London." Anthropology \& Medicine 20, 3 (2013).

Mahali, Saidatul Nornis Hj. "Latar Masyarakat Bajau". Saidatul Nornis Hj. Mahali (ed.). Bajan Pantai Barat. Sabah: Universiti Malaysia Sabah, 2012.

Nagatsu, K. "Maritime Diaspora and Creolization: Genealogy of the Sama-Bajau in Insular Southeast Asia." Senri Ethnological Studies, 95 (2017).

-------. "Social Space of the Sea Peoples: A Study on the Arts of Syncretism and Symbiosis in the Southeast Asian Maritime World." The Journal of Sophia Asian Studies, 33 (2015).

Noor, Farish A. "Conversion Narratives and the Appropriation of India in the Southeast Asian Tablighi Jama'at Movement." Michael Feener and Terenjit Sevea (eds.). Islamic Connections: Studies of Muslim South and Southeast Asia. Singapore: ISEAS, 2008.

--------. "Pathans to the East! The Development of the Tablighi Jama'at Movement in Northern Malaysia and Southern Thailand." Comparative Studies of South Asia, Africa and the Middle East 27, 1 (2007).

-. "The Arrival and Spread of the Tablighi Jama'at in West Papua (Irian Jaya), Indonesia.” RSIS Working Papers Series no. 191, Nanyang Technological University, Singapore, 2010.

-. "The Spread of the Tablighi Jama'at across Western, Central, and Eastern Java and the Role of the Indian Muslim Diaspora." RSIS Working Papers Series no. 175, Nanyang Technological University, Singapore, 2009.

-. "The Tablighi Jama'at in the Southern Provinces of Thailand Today: Networks and Modalities". RSIS Working Papers Series no. 174, Nanyang Technological University, Singapore, 2009.

. Islam on the Move: The Tablighi Jama'at in Southeast Asia. Amsterdam: Amsterdam University Press, 2012.

Pelras, C. The Bugis. Oxford: Blackwell Publishers, 1996.

Rahim, Md. Saffie Abd. and Ramzah Dambul. "Identiti Etnik Bajau Pantai Timur." Md. Saffie Abd. Rahim, Sabihah Osman, and 
Ramzah Dambul (eds). Bajau Pantai Timur. Sabah: Universiti Malaysia Sabah, 2012.

Ringgren, H. "Islamic Fatalism." Helmer Ringgren (ed.). Fatalistic Beliefs in Religion, Folklore, and Literature. Stockholm: Almqvist \& Wiksell, 1967.

Saat, Gusni. Sama Bajau dalam Kanca Urbanisasi: Pengalaman di Teluk. Bone, Sulawesi Selatan. Kuching: Universiti Malaysia Sarawak, 2010.

Sakdiah. "Masthurah dalam Dakwah Jama'ah Tabligh: Analisis Metode dan Praktek." Al-Idarah 1, 1 (2017).

Saprillah. "Gerakan Salafisme di Kota Kendari." Mimikri 3, 1 (2017).

Siddik, Ibnu Radwan. "The Husband's Obligation in Giving Religious Education for His Wife According to Compilation of Islamic Law and its Implementation on Tablighi Jama'at in Serdang Bedagai, North Sumatra, Indonesia." IOSR Journal Of Humanities And Social Science 22, 4 (2017).

Sila, M. Adlin. "Kasus Jama'ah Tabligh di Makassar Sulawesi Selatan dan Magetan Jawa Timur." Ahmad Syafi'í Mufid (ed.). Perkembangan Paham Keagamaan Transnasional di Indonesia. Jakarta: Kementerian Agama, 2011.

Simsekoglu, O. et.al. "Risk Perceptions, Fatalism and Driver Behaviors in Turkey and Iran." Safety Science 59 (2013).

Talib, M. "The Tablighis in the Making of Muslim Identity." Mushirul Hasan (ed.). Islam, Communities and the Nation, Muslim Identities in South Asia and Beyond. New Delhi: Manohar Publishers, 1998.

Wahid, Abdurrahman. Ilusi Negara Islam: Ekspansi Gerakan Islam Transnasional di Indonesia. Jakarta: LibForAll Foundation, 2009.

Zacot, F.R. Orang Bajo, Suku Pengembara Laut. Jakarta: Gramedia, 2008. 